\title{
Criteria for long-stay care
}

\author{
David Jolley, Susan Jolley and Susan Benbow
}

Most old age psychiatrists see long-stay care in good quality community hospitals as an essential component of a comprehenstve service for older people suffering from mental illnesses (Jolley \& Arie, 1992). Yet in recent years some Health Authorities have sought to reduce or close their long-stay beds and this has caused a great deal of controversy (Alzheimer's Disease Society, 1993; Benbow et al, 1994).

New guidance from the Department of Health makes it very clear that the NHS has a responsibility to provide a reasonable number of longstay beds for this patient group. Authorities are required to agree and to publish criterla for admission to such facilities and a mechanism is envisaged which will allow investigation of appeals (Department of Health, 1995).

How common is it for Authorities to have written criteria avallable now? What are the criteria identified, are they likely to meet the requirements of the new guidance and can they be useful to others who are only now addressing this exercise?

\section{The study}

In preparation for a consensus meeting on the topic, from which it was intended to offer advice through the College, a request for information on current practice was circulated to 139 old age psychiatrists, distributed through the 15 Regions of England and Wales.

\section{Findings}

Eighty-eight replies were received. Twenty-seven (31\%) services are already using written criteria, usually agreed with social service departments and others. Fourteen different statements of criteria were provided by respondents, there being two 'standard' lists in use by services in Wessex, and some respondents declared they were using written criterla but did not make them available. The context in which work is done and criteria will have to be applied covers a considerable range: seven of the $\mathbf{8 8}$ services have no access to long-stay beds. The average provision is 1.7 beds/1000 over 65 years, with respite beds included; the most generous Authority provides 4.5 beds/1000. All but $15 \%$ of long-stay beds are provided directly by the NHS as are $81 \%$ of respite beds.

It was not possible to define a relationship between the criteria in written statements of eligibility and the level of NHS provision as only a proportion of services had such statements and made them available, but it must be the case that de facto criteria differ widely. Analysis of those written criteria which have been made available reveals a number of common themes (Table 1). Most include a requirement for clinical judgement from a consultant within a multidisciplinary team. None make use of numerical scales and all emphasise the presence of multiple, complex. changeable needs among the patients to be offered long-term care. Inclusion criteria couched

Table 1. Citteria for admission to long-stay psychogeriatric beds

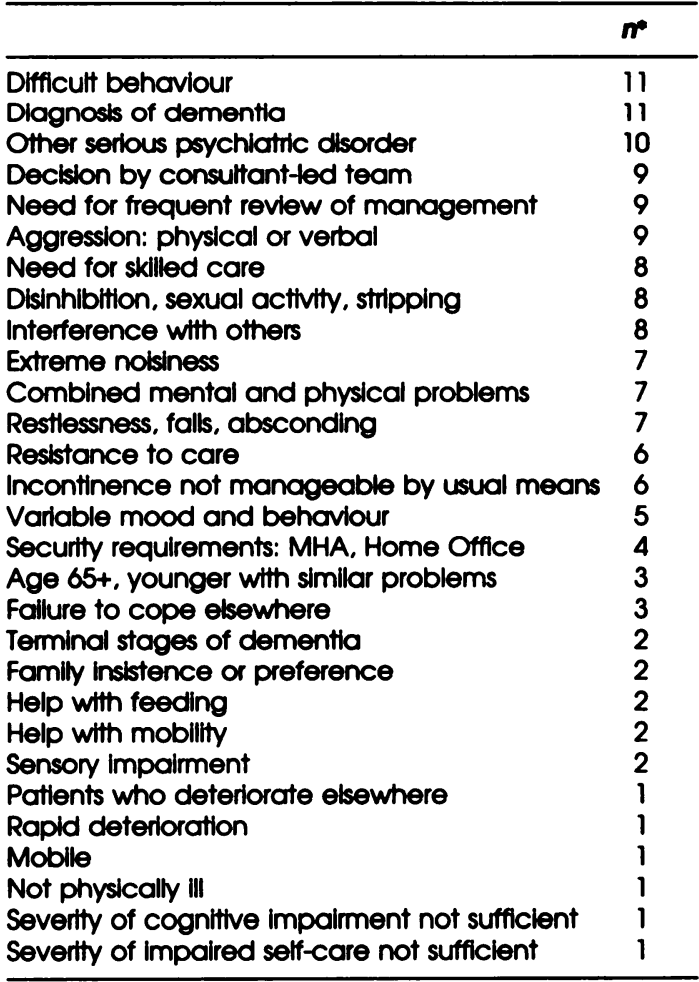

-Numbers refer to the frequency with which individual citteria were mentioned in 14 witten returns 
in wider terms were found in most statements (criteria 1-7) with mention of specific behaviours or characteristics being less common and sometimes idiosyncratic. Very few exclusion criteria were identified and exclusion for one might be a specific inclusion for another, e.g. 22/26.

\section{Comment}

Most Authorities will need to establish written criterla for the first time to comply with the new guidance. While those with established criteria will be reassured that most share a common set of basic requirements, this must conceal wide differences in practice or interpretation because of the range of provision which exists. It is doubtful if any of these extant statements will stand up to the rigours of an appeal procedure addressed to discontent in individual cases but they do offer a glimpse of the sort of characteristics of patients likely to be included in long-term care and could form the basis from which a national framework of criterla can emerge.

\section{References}

ALZHEIMER'S DISEASE SOCIETY (1993) NHS Conttruing Care Beds. London: ADS.

Benbow, S. M., Jouley, D. \& Tomenson, B. (1994) Provision of residential care for vulnerable old people. Journal of Mental Health, 3, 235-240.

DEPARTMENT OF HEALTH (1995) NHS Responsibiltties for Meeting Conttnuting Health Care Needs. HSG(95)8, LAC(95)5. London: DoH.

JOLEY, D. \& ARIE, T. (1992) Developments in psychogerlatric services. In Recent Advances in Psychogerlatrics II (ed T. Arie). pp. 117-135. Edinburgh: Churchill Ltvingstone.

-David Jolley, Consultant Old Age Psychiatrist, South Manchester NHS Trust and Wolverhampton NHS Trust, Susan Jolley, Consultant Old Age Psychiatrist, South Manchester NHS Trust; and Susan Benbow, Consultant Old Age Psychiatrist. Central Manchester NHS Trust

"Correspondence: Dr D. Jolley, Psychogerlatric Unit, Withington Hospital, Nell Lane, West Didsbury, Manchester M20 8LR

\title{
Management for Psychiatrists Second Edition
}

\author{
Edited by Dinesh Bhugra and Alistair Burns
}

Since the last edition rapid changes in the NHS have meant that clinicians have had even less time to manage change and keep up to date with health reforms. For this new edition, all the existing material has been extensively revised. In addition, eight new chapters have been added, including a section on changes and conflicts covering large areas of potential difficulty that clinicians may have to deal with.

As before, the emphasis is on how to get the best for and from services. Practical advice is given on management. Negotiation techniques and time and stress management are also covered.

- $20.00 \bullet 360 p p . \odot 1995 \bullet$ ISBN 0902241850

Available from bookshops and from the Publications

Department, Royal College of Psychiatrists, 17 Belgrave Square,

London SW1X 8PG (Tel. 0171-235 2351 extension 146) 